anales de psicología / annals of psychology

2019, vol. 35, $\mathrm{n}^{\circ} 3$ (october), 506-513

http://dx.doi.org/10.6018/analesps.35.3.354941
(C) Copyright 2019: Editum. Servicio de Publicaciones de la Universidad de Murcia. Murcia (Spain) ISSN print edition: 0212-9728. ISSN on line edition (http://revistas.um.es/analesps): 1695-2294.

On line edition License Creative Commons 4.0: BY-NC-ND

\title{
Influence of personality variables, impulsivity, perfectionism, self-esteem and self-efficacy in Work Craving
}

María-José Serrano-Fernández ${ }^{1 *}$, Joan Boada-Grau ${ }^{1}$, Jordi Assens-Serra ${ }^{2}$, Maria Boada-Cuerva ${ }^{1}$, and Andreu Vigil-Colet ${ }^{1}$

1 Universitat Rovira i Virgili, URV, Tarragona (Spain)

2 EADA, Business School, EADA, Barcelona (Spain)

\begin{abstract}
Título: Influencia de las variables de personalidad, impulsividad, perfeccionismo, autoestima y autoeficacia en el Work Craving

Resumen: Estudios recientes has sugerido que hay relación entre algunas variables de personalidad y la adicción al trabajo. En el presente trabajo nos hemos planteado el objetivo de realizar un estudio Predictivo de las variables antecedentes del Work Craving a través de las variables Impulsividad, Personalidad, Perfeccionismo, Autoestima y Autoeficacia.: Los participantes han sido 332 trabajadores, obtenidos mediante un muestreo no probabilístico. Para analizar los datos se ha utilizado el programa SPSS 23.0. Los resultados del análisis de correlación nos muestran asociaciones tanto positivas como negativas con las variables estudiadas. El análisis de regresión determina la capacidad predictiva de las variables Estabilidad emocional, Perfeccionismo y Autoestima que explican el $24.40 \%$ de la varianza de los Sentimientos Generados por el Trabajo (WCS.FW). Y las variables Estabi lidad emocional y Autoestima explican el $14.0 \%$ de la Necesidad de trabajar (WCS.NW). Se puede concluir que el Work Craving puede predecirse a través de determinadas variables (Estabilidad emocional, Perfeccionismo y Autoestima), contribuyendo la presente investigación a un mayor conocimiento de la Adicción al Trabajo. Los resultados poseen implicaciones prácticas importantes que debe considerarse para la gestión estratégica adecuada de los recursos humanos dentro de las organizaciones. Los más notables entre ellos son la necesidad de promover la mejora de la autoestima y la estabilidad emocional.
\end{abstract}

Palabras clave: adicción al trabajo, work Craving, salud laboral, necesidades psicológicas, personalidad

\section{Introduction}

It is becoming increasingly common to encounter people who have a constant need to work, and this affects their social relationships, their happiness and their health. This phenomenon was described by Oates as early as 1968, who coined the term Workaholism (work addiction). Workaholics spend excessive time working, which has negative repercussions on their social and family relationships and their leisure time (Scott, Moore, \& Miceli, 1997). They have high expectations from their work, beyond the actual requirements of their jobs and their own economic needs (Scott et al., 1997). They devote more energy to their work than is strictly necessary (Andreassen, Ursin, \& Eriksen, 2007), and the persistence and frequency they devote to their work makes them think about it even when they are not working (Scott et al., 1997). The criteria most frequently used in the literature to diagnose work addiction are obsessive thinking about work and repeated efforts to disconnect from work (e.g. McMillan,

* Correspondence address [Dirección para correspondencia]

Dra. María-José Serrano-Fernández. Universitat Rovira i Virgili. Faculty of Education Sciences and Psychology, Campus Sescelades. Ctra Valls, s/n, Tarragona 43007 (Spain). E-mail: mariajose.serrano@urv.cat (Article received: 20-12-2018; revised: 17-4-2019; accepted: 7-5-2019)
Abstract: Recent studies have suggested a relationship between certain personality variables and work addiction. In the present work we conduct a predictive study of the background variables of work craving through the variables Impulsivity, Personality, Perfectionism, Self-esteem and Selfefficacy. The participants were 332 workers obtained by non-probability sampling. We used the SPSS 23.0 program. The results of the correlation analysis show positive and negative associations with the variables studied. The regression analysis determines the predictive capacity of variables Emotional Stability, Perfectionism and Self-esteem account for $24.40 \%$ of the variance of Feelings Generated by Work (WCS.FW). And the predictor variables Emotional stability and Self-esteem account for $14.0 \%$ of the Need to Work (WCS.NW). It can be concluded that Work craving can be predicted through certain variables (Emotional Stability, Perfectionism and Self-esteem). This research contributes to greater knowledge of work addiction. The results have important practical implications to work that should be considered for the appropriate strategic management of human resources within organizations. The most notable among these are the need to promote the enhancement of self-esteem and emotional stability. Keywords: workaholism; work Craving; occupational health; psychological needs; personality.

\& O’Driscoll, 2006; Robinson, 2007; Schaufeli, Shimazu, \& Taris, 2009). These characteristics highlight the fact that workaholics, much like gamblers, sometimes experience an overwhelming and often irresistible desire to participate in a certain behavior, in this case work (Wojdylo, Baumann, Buczny, Owens, \& Kuhl, 2013).

The lack of a tool to measure desire in the context of work was a limitation in studying this phenomenon until Wojdylo (2013) proposed a novel model for assessing workaholism. According to the model, the main mechanism of work addiction is the compensatory function of emotions. This explains why workaholics, like other types of addicts, experience an intense desire for emotional compensation. This compensatory function is an inherent characteristic of addiction and includes compulsive (behavioral), hedonic (emotional) and learned (cognitive) components, representing a new way of contextualizing and measuring addiction, the craving to work, which we will refer to as Work Craving (WC).

The theory of work craving defines workaholism as a pathological work addiction which comprises four dimensions: (a) the obsessive-compulsive desire to work, which is the state in which the obsessive desire to work constantly predominates, manifested in obsessive thoughts and/or compulsive participation in work; (b) the anticipation of 
compensatory incentives for self-worth derived from work, which describes the hedonistic component, including expectations related to raising self-worth (sense of competence, efficiency) as a result of the obsessive commitment to work; (c) the anticipation of negative affect reduction (relief) and withdrawal symptoms, which explains the component that contains hedonistic expectations related to the reduction of negative emotions (irritability, guilt, depression) and withdrawal symptoms (fatigue, exhaustion) as a result of the obsession with work; and (d) neurotic perfectionism, which is the tendency to set unrealistic performance goals and interpret the failure to achieve those standards as failure in general, and a lack of belief or confidence in one's ability to do anything correctly (Wojdylo et al., 2013; Wojdylo, Karlsson, \& Baumann, 2016). However, the obsession or compulsion to work is only one subcomponent of Work Craving. Davison and Neale (1990) indicated that one of the components of the absence of craving in obsessive-compulsive people is the anticipation of positive moods (feelings of selfesteem) after work.

This study attempts to verify whether work craving can be predicted through certain variables. Hameed, Amjad and Hameed (2013) conducted a study to determine if personality could predict work addiction, demonstrating that personality is related to work addiction and that work addiction can be considered a stable factor of personality (Burke, Matthiesen, \& Pallesen 2006). An empirical study by Mazzetti, Schaufeli and Guglielmi (2014) demonstrates empirically that a work environment characterized by a climate of overwork can promote work addiction, especially for workers with high achievement motivation, perfectionism, responsibility and self-efficacy. The last two are related to work addiction only when they occur in interaction with an excessive work climate. A relationship between pathological perfectionism and low self-esteem has also been found (Hill, Huelsmann, Furr, Kibler, Vicente, \& Kennedy, 2004; Slade \& Owens, 1998; Terry-Short, Owens, Slade, \& Dewey, 1995).

Van Wijhe, Peeters and Schaufeli (2014) found that workaholics have rigid personal beliefs, in other words, their self-esteem depends on the satisfactory performance of the task, which is related to the dimensions in Wojdylo's work craving model (2013). Porter's studies (1996) also support the assumption about the relationship between pathological perfectionism, the obsessive work activities of workaholics and self-esteem. Workaholics repeatedly engage in the same obsessive behavior in an effort to achieve perfection. The work of several authors has established that work addiction is associated with low self-esteem (Burke, 1999, 2000a, 2000b; Chamberlin \& Zhang, 2009). Workaholics set unrealistically high standards for overly high levels of performance and are very concerned about making mistakes: Every error is perceived as a threat to their self-esteem (Wojdylo et al., 2013).

Wojdylo $(2007,2010)$ shows that the persistence of workaholics is largely oriented towards obtaining favorable competitive judgments and avoiding unfavorable judgments.
Other authors indicate that the orientation towards performance objectives and excessive concern about errors are facets of a negative (pathological) form of perfectionism (Stoeber, \& Otto, 2006; Terry-Short et al., 1995). Therefore, neurotic perfectionism may be another important component of the craving for work (Wojdylo et al., 2013). Wojdylo, Baumann and Kuhl (2017) shows that work craving was predicted by high self-control and low self-regulation and associated with higher psychological distress, work engagement was predicted by high self-regulation and high self-control and associated with lower symptoms of psychological distress.

Impulsive traits are seen as the key to initiate the behavior which leads the individual to perform the behavior compulsively (Dell'Osso, Altamura, Allen, Marazziti, \& Hollander, 2006). Impulsivity has also been identified as an important predisposing factor in other types of addictions such as internet addiction (Cao, Su, Liu, \& Gao, 2007; Choi, Park et al., 2014; Lee et al., 2012) and online gaming (Choi, Kim et al., 2014; Ding et al., 2014; Metcalf \& Pammer, 2014; Nuyens et al., 2016). In addition, Stamates and Lau-Barraco (2017) positively associated impulsivity with the desire for alcohol and caffeine. Griffiths, Demetrovics and Atroszko (2018) demonstrated that there is evidence that work addiction in some respects is dissimilar to other behavioral addictions. That is why in this research we want to see the role of impulsivity in the work Craving.

The Work Craving is a relatively new construct that requires investigation in this research aims to develop a predictive model of work craving using the indicators of Personality: Impulsivity, Extraversion, Emotional stability, Conscientiousness, Agreeableness, Openness to experience, Perfectionism, Self-esteem and Self-efficacy, with the following objectives:

Objective 1: If the feelings generated by work (WCS.FW) are influenced by Impulsivity, Extraversion, Emotional stability, Conscientiousness, Agreeableness, Openness to experience, Perfectionism, Self-esteem and Self-efficacy, then a model that incorporates these predictors can accurately predict the feelings generated by work.

Objective 2: If the need to work (WCS.NW) is influenced by Impulsivity, Extraversion, Emotional stability, Conscientiousness, Agreeableness, Openness to experience, Perfectionism, Self-esteem and Self-efficacy, then a model that incorporates these predictors can accurately predict the need to work.

\section{Method}

\section{Participants}

The study participants were 332 employed or selfemployed workers who were active at the time of data collection. All of them live in Spain. Table 1 shows, Gender, Age, Marital status, Seniority, Education level and Professional group, the sociodemographic characteristics of the 
participants in the sample. The participants responded voluntarily and did not receive any kind of gratification, they also signed an informed consent. The confidentiality of the data the participants provided is fully guaranteed.

Table 1. Sociodemographic characteristics of the participants.

\begin{tabular}{lll}
\hline Variable & & $(\mathrm{N}=332)$ \\
\hline Gender (\%) & Men & $49.1 \%$ \\
Age (years) & Women & $50.9 \%$ \\
Marital status (\%) & & $M=44.33(S D=11.71)$ \\
& Married or de-facto union & $63.30 \%$ \\
& Single & $22.6 \%$ \\
Seniority (years) & Widorced / Separated & $12.0 \%$ \\
& In the current job & $2.1 \%$ \\
In the profession & $M=9.35(S D=9.8)$ \\
Education level & In the current company & $M=15.24(S D=12.44)$ \\
& Without studies (no academic qualifications) & $M=11.49(S D=11.15)$ \\
& Completed primary education & $1.8 \%$ \\
& Completed secondary education & $17.5 \%$ \\
& Finished university studies & $45.8 \%$ \\
Professional group & Master's / doctorate studies completed & $25.3 \%$ \\
& Executive & $9.6 \%$ \\
& Professionals, scientists and intellectuals & $6.9 \%$ \\
& Mid-level professionals & $14.5 \%$ \\
& Administrative workers & $15.1 \%$ \\
& Service workers, vendors in shops and markets & $11.3 \%$ \\
& Farmers and skilled agricultural, forestry and fishing workers & $30.1 \%$ \\
& Office workers and operators & $3,3 \%$ \\
& Unskilled workers & $12.2 \%$ \\
& Military and police officers & $4.5 \%$ \\
& & $2.1 \%$ \\
\hline
\end{tabular}

\section{Instruments}

Below are the instruments used in this study. The alpha coefficients are those obtained in the original validation studies of the instruments.

To measure Work Craving we used the Spanish version of the Work Craving Scale (WCS; Wojdylo et al., 2013), adapted by Serrano-Fernández, Boada-Grau, Assens-Serra, Boada-Cuerva and Vigil-Colet (n.d.). It consists of 10 items and 2 subscales and uses a Likert-type response format. The factors were: "F1. Feelings generated by work (WCS.FW)", made up of 5 items $(\alpha=.87)$ (e.g. "7. Tengo que trabajar duro para sentirme eficaz en lo que estoy haciendo [I need to work hard in order to feel effective in what I'm doing]"); and "F2. Need to work (WCS.NW)", made up of 5 items $(\alpha=$ .84) (e.g. "19. Si ahora estuviera trabajando en exceso me sentiría menos cansado [Working excessively now would make me less tired]").

To measure Impulsivity, we used Dickman's Impulsivity Inventory (DII; Dickman, 1990), in its Spanish version (Chico, Tous, Lorenzo-Seva, \& Vigil-Colet, 2003), which is made up of 23 items and 2 subscales and makes use of a dichotomous response format $(1=$ true $/ 0=$ false $)$. The factors were "F1. Functional impulsiveness" assesses impulsiveness that is beneficial and that helps one adapt to unexpected situations which require a quick response. It is made up of 11 items $(\alpha$ $=.77$ ) (e.g. "5. La mayor parte del tiempo puedo concentrarme en mis trabajos de forma rápida [Most of the time I can concentrate on my work very quickly]"). And "F2. Dysfunctional impulsiveness" refers to impulsiveness that, far from being helpful, can be counterproductive, and is made up of 12 items $(\alpha=.76)$ (e.g. " 2 . Frecuentemente digo lo primero que se me ocurre sin pensar mucho antes [I frequently say the first thing that comes to my head without giving it much thought]").

Personality was assessed with the Personality Inventory (OPERAS; Vigil-Colet, Morales-Vives, Camps, Tous, \& Lorenzo-Seva, 2013), an instrument based on the Big Five personality traits. It includes 40 items to which subjects respond using a 5 -point scale. It measures Extraversion (alpha $=.86$ ) (e.g. "8. Me desenvuelvo bien en situaciones sociales [I perform well in social situations]"), Emotional Stability ( $a=.86)$ (e.g. "9. A menudo tengo el ánimo por el suelo [I often feel down in the dumps]"), Conscientiousness $(a=.77)$ (e.g. "16. Dejo las cosas a medias [I leave things half done]"), Agreeableness $(a=.71)$ (e.g. "12. Respeto a los demás [Respect for others]"), and Openness to Experience $(a=.81)$ (e.g. "35. Siento curiosidad por el mundo que me rodea [I'm curious about the world around me]"). The response format is a 5point Likert scale $(1=$ totally disagree to $5=$ totally agree $)$.

The Obsessive-Compulsive component was assessed using part of the Spanish version of the Revised Obsessional Intrusions Inventory (COI; Belloch, Cabedo, Morillo, Lucero, \& Carrió, 2003). Made up of 58 items and 7 subscales, it uses a 7-point Likert-type response scale. We only used one factor: "F2. Perfectionism and intolerance of un- 
certainty", consisting of 14 items $(\alpha=.86)$ (e.g. "2. Debo ser el/la mejor en aquello que es importante para mí [I must be the best at what is important to me]").

Rosenberg's Self-esteem Scale (SES; Rosenberg, 1965), adapted by Martín-Albo, Núñez, Navarro and Grijalvo (2007), was used to evaluate Self-esteem and consists of a 10 -item scale that assesses global self-esteem by measuring one's positive and negative feelings about oneself. Scoring options range from 1 (strongly disagree) to 4 (strongly agree). The SES is a one-dimensional instrument of average reliability (.77 to .88) (e.g. "4. Soy capaz de hacer cosas tan bien como la mayoría de las otras personas [I can do things as well as most other people]").

To assess self-efficacy, we used the Spanish version of the General Self-Efficacy Scale (GSE; Baessler \& Schwarcer, 1996), adapted by Sanjuán, Pérez and Bermúdez (2000). This scale is a one-factor scale made up of 10 items, $(\alpha=.87)$ (e.g. "8. Puedo resolver la mayoría de los problemas si me esfuerzo lo necesario [If I make enough of an effort I can solve most problems]"). The response format is a 4-point Likert scale. $(1=$ false to $4=$ true $)$.

\section{Procedure}

We used non probabilistic sampling (Hernández, Fernández, \& Baptista, 2000), also known as accidental sampling (Kerlinger, 2001) to obtain the sample. The response rate was approximately $80 \%$. The selection of participants was carried out through the social and business network. Participants were informed that the study was an initiative of the
Spitzen Value Research Group, Human Resources of the Rovira i Virgili University of Tarragona. That the data obtained is totally confidential and anonymous. A protocol was prepared for the participant that included a cover letter, informed consent and the questionnaires to be answered. The questionnaires were answered at their usual workplace. The research complies with the ethical principles of the Helsinki Convention.

\section{Data Analysis}

First, the Kolmogorov-Smirnov test is used to check the normality of the data, showing this a good fit. The next step in the analysis was to use Pearson's correlation coefficients to calculate the correlations between the predictor variables and the criterion variables. Subsequently multiple regressions are performed using the stepwise option, where by the program enters each predictor variable into the model according to the extent to which it accounts for variance. We used the SPSS 23.0 program.

\section{Results}

\section{Reliability analysis}

Table 2 shows the instruments used. The internal consistency indices using the coefficient Omega (McDonald, 1999) are appropriate, given that they range between .74 (Openness to experience) and .94 (Functional impulsivity).

Table 2. Descriptive statistics and reliability values with Cronbach's alpha coefficient.

\begin{tabular}{|c|c|c|c|c|c|}
\hline Variable & Minimum & Maximum & Mean & $S D$ & $\omega$ \\
\hline IM.F1. Functional impulsivity & 2 & 9 & 5.64 & 1.34 & .94 \\
\hline IM.F2. Dysfunctional impulsivity & 2 & 10 & 5.67 & 1.42 & .79 \\
\hline Op.EX Extraversion & 17 & 79 & 47.58 & 10.08 & .76 \\
\hline Op.ES Emotional stability & 16 & 77 & 49.77 & 10.69 & .78 \\
\hline Op.CO Conscientiousness & 9 & 76 & 51.53 & 9.77 & .77 \\
\hline Op.AG Agreeableness & 2 & 78 & 50.68 & 11.38 & .78 \\
\hline Op.OE Openness to Experience & 18 & 68 & 49.25 & 10.62 & .74 \\
\hline Perfectionism & 14 & 98 & 70.99 & 15.24 & .93 \\
\hline Self-Esteem & 0 & 20 & 13.23 & 4.29 & .87 \\
\hline GSE. Self-efficacy & 10 & 40 & 31.58 & 4.73 & .90 \\
\hline WCS.FW. Feelings Generated by Work & 5 & 32 & 14.04 & 7.11 & .90 \\
\hline WCS-NW. Need to Work. & 5 & 32 & 8.84 & 5.12 & .91 \\
\hline
\end{tabular}

\section{Correlation analyses}

The correlational study table below (Table 3) only shows the correlations between the criterion variables and the predictor variables in this study.

We found a positive correlation between feelings generated by work (WCS.FW), and two predictor variables Extra- version $(r=.145, p=.01)$ and Perfectionism $(r=.323, p=$ $.01)$ and negative correlation with Emotional Stability $(r=$ $.399, p=.01)$ and Self-esteem $(r=-.336, p=.01)$. Need to work (WCS.NW) correlated negatively with two predictor variables Emotional Stability $(r=-.295, p=.01)$ and Selfesteem $(r=-.348, p=.01)$. 
Table 3. Correlations between the predictor variables and the criterion variables.

\begin{tabular}{lcc}
\hline Predictor variables & \multicolumn{2}{c}{ Criterion variables } \\
& WCS-FW & WCS-NW \\
\hline IM.F1.Functional impulsivity & -.047 & -.074 \\
IM.F2. Dysfunctional impulsivity & .065 & .079 \\
Op.EX Extraversion & $.145^{* *}$ & .041 \\
Op.ES Emotional stability & $-.399^{* *}$ & $-.295^{* *}$ \\
Op.CO Conscientiousness & .021 & -.086 \\
Op.AG Agreeableness & -.054 & -.026 \\
Op.OE Openness to Experience & -.013 & -.099 \\
Perfectionism & $.323^{* *}$ & .102 \\
Self-Esteem & $-.336^{* *}$ & $-.348^{* *}$ \\
Self-efficacy & .022 & -.097 \\
\hline
\end{tabular}

** The correlation is significant at 0.01 (bilateral). ${ }^{*}$ The correlation is significant at 0.05 (bilateral).

Variables: Feelings Generated by Work (WCS.FW), Need to Work (WCSNW), Functional impulsivity (IM.F1), Dysfunctional impulsivity (IM.F2), Extraversion (Op.EX), Emotional stability (Op.ES), Conscientiousness (Op.CO), Agreeableness (Op.AG), Openness to Experience (Op.OE), Perfectionism (Perfec), Self-Esteem and Self-efficacy.

\section{Multiple regression}

We used a multiple linear regression analysis to test the effects of ten predictor variables (Functional impulsivity (IM.F1), Dysfunctional impulsivity (IM.F2), Extraversion (Op.EX), Emotional stability (Op.ES), Conscientiousness (Op.CO), Agreeableness (Op.AG), Openness to Experience (Op.OE), Perfectionism (Perfec), Self-Esteem and Selfefficacy) on the criterion variables related to work craving (see figure 1). Two multiple linear regression models were used for this purpose.

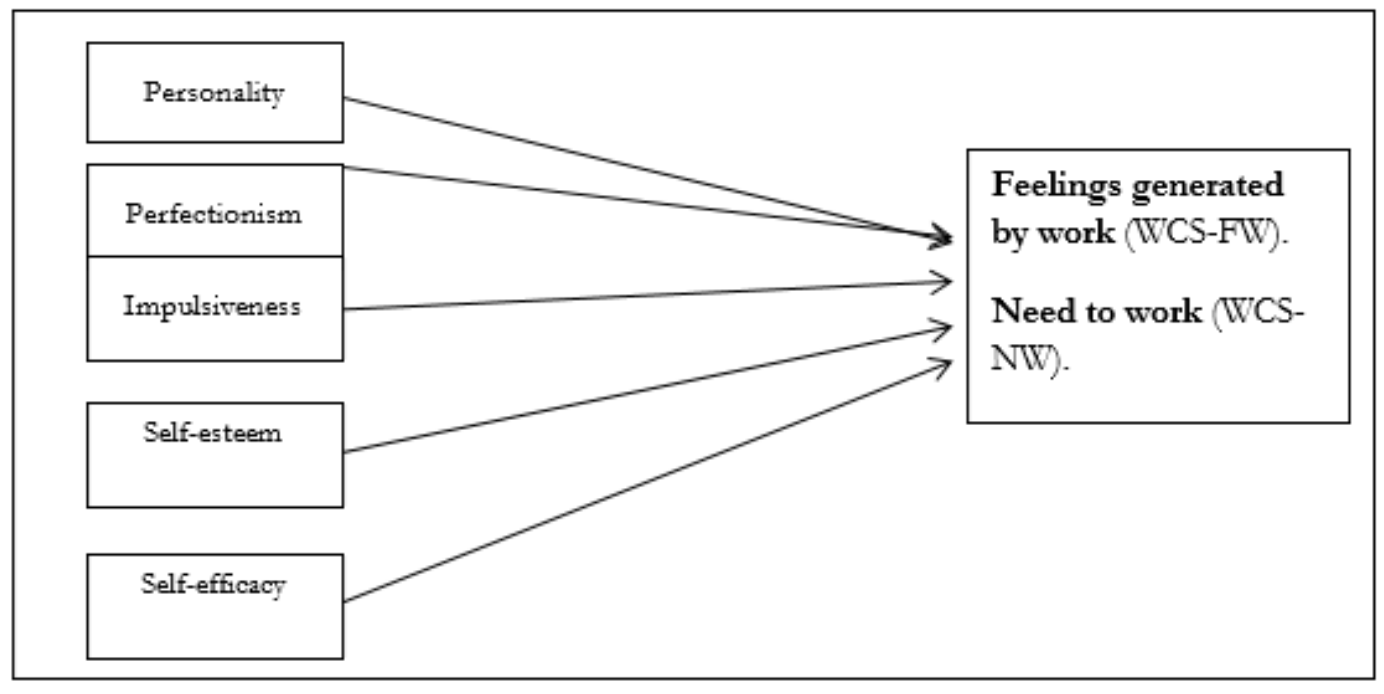

Figure 1. Model followed in this research.

The first model aimed to identify the degree to which these predictor variables were capable of predicting the criterion variable Feelings Generated by Work (WCS.FW). Table 4 presents a summary of the model which shows that the predictor variables Emotional Stability, Perfectionism and Selfesteem account for $24.40 \%$ of the variance of this criterion variable. The Emotional Stability variable stands out as the best predictor, accounting for $15.6 \%$ of variance. Among the most important aspects are the beta coefficient values. If we take a look at these coefficients we can see that the predictor variables which were found to be statistically significant were: Emotional stability $(\beta=-.187)$, Perfectionism $(\beta$ $=.270)$ and Self-esteem $(\beta=-.265)$. 
Table 4. Summary of the models, variables and coefficients of regression analysis (stepwise method) for the Feelings Generated by Work (WCS-FW).

\begin{tabular}{|c|c|c|c|c|c|c|c|c|c|c|c|}
\hline \multirow[b]{2}{*}{ Models and Variables } & \multicolumn{6}{|c|}{ Models } & \multicolumn{5}{|c|}{ Coefficients } \\
\hline & $\mathrm{R}$ & $\mathrm{R}^{2}$ & R2 Adjusted & $\mathrm{R}$ Change & FChange & $\operatorname{sig}$ & B & SE & $\beta$ & $t$ & sig \\
\hline Model-1 & .399 & .159 & .156 & .159 & 62.354 & .000 & & & & & \\
\hline Op.ES & & & & & & & -.265 & .034 & -.399 & -7.896 & .000 \\
\hline Model-2 & .445 & 198 & 193 & .039 & 16.069 & .000 & & & & & \\
\hline Op.ES & & & & & & & -.217 & .035 & -.326 & -6.198 & .000 \\
\hline Perfec & & & & & & & .098 & .025 & .211 & 4.009 & .000 \\
\hline Model-3 & .501 & .251 & 244 & .053 & 23.126 & .000 & & & & & \\
\hline Op.ES & & & & & & & -.124 & .039 & -.187 & -3.194 & .002 \\
\hline Perfec & & & & & & & .126 & .024 & .270 & 5.159 & .000 \\
\hline Self-Esteem & & & & & & & -.439 & .091 & -.265 & -4.809 & .000 \\
\hline
\end{tabular}

Introduced variables: Functional impulsivity (IM.F1), Dysfunctional impulsivity (IM.F2), Extraversion (Op.EX), Emotional stability (Op.ES), Conscientiousness (Op.CO), Agreeableness (Op.AG), Openness to Experience (Op.OE), Perfectionism (Perfec), Self-Esteem and Self-efficacy.

Excluded variables: Functional impulsivity, Dysfunctional impulsivity, Extraversion, Conscientiousness, Agreeableness, Openness to Experience and Selfefficacy.

The second model analyzed the variables' ability to predict the criterion variable Need to Work. (WCS.NW). The model is summarized in Table 5 and shows that the predictor variables Emotional stability and Self-esteem account for $14.0 \%$ of the criterion variable's variance, whereas the varia- ble Self-esteem is the best predictor, accounting for $11.90 \%$ of variance. The beta coefficient values were Self-esteem $(\beta=$ -.271) and Emotional Stability $(\beta=-.173)$. Negative correlations were also found between the variables Emotional Stability $(r=-.295, p=.01)$ and Self-esteem $(r=-.348, p=.01)$.

Table 5. Summary of the models, variables and coefficients of regression analysis (stepwise method) for the Need to Work (WCS-NW).

\begin{tabular}{|c|c|c|c|c|c|c|c|c|c|c|c|}
\hline \multirow[b]{2}{*}{ Models and Variables } & \multicolumn{6}{|c|}{ Models } & \multicolumn{5}{|c|}{ Coefficients } \\
\hline & $\mathrm{R}$ & $\mathrm{R}^{2}$ & R2 Adjusted & R Change & F Change & $\operatorname{sig}$ & B & SE & $\beta$ & $\mathrm{t}$ & sig \\
\hline Model-1 & .348 & .121 & .119 & .121 & 45.565 & .000 & & & & & \\
\hline Self-Esteem & & & & & & & -.416 & .062 & -.348 & -6.750 & .000 \\
\hline Model-2 & .381 & .145 & .140 & .024 & 9.262 & .003 & & & & & \\
\hline Self-Esteem & & & & & & & -.323 & .068 & -.271 & -4.747 & .000 \\
\hline Op ES & & & & & & & -.083 & .027 & -.173 & -3.043 & .003 \\
\hline
\end{tabular}

Introduced variables: Functional impulsivity (IM.F1), Dysfunctional impulsivity (IM.F2), Extraversion (Op.EX), Emotional stability (Op.ES), Conscientiousness (Op.CO), Agreeableness (Op.AG), Openness to Experience (Op.OE), Perfectionism (Perfec), Self-Esteem and Self-efficacy.

Excluded variables: Functional impulsivity, Dysfunctional impulsivity, Extraversion, Conscientiousness, Agreeableness, Perfectionism, Openness to Experience and Self-efficacy.

\section{Discussion}

The results presented above are consistent with the notion that certain variables can predict the factors studied in relation to Work Craving.

The first objective is partially confirmed given that our results show that the best predictive model includes three variables: positively, Perfectionism and negatively, Emotional Stability and Self-esteem.

Self-esteem negatively predicts Work Craving, which is in concordance with that found by Burke (1999), Chamberlin and Zhang (2009), and Wojdylo et al. (2013). The variable Perfectionism has also been included in the model as a positive predictor. This coincides with the work of Mudrack (2004), who explored the relationship between the features of obsessive-compulsive personality and addiction to work and determined that high Work Involvement coupled with high scores on Obsessive-Compulsive trait scales lead people to work unnecessarily. Of the personality variables, measured through the 5-factor model, only the Emotional Stability variable is included in the model as a negative predictor (Tables 6). This coincides with Del Líbano's (2011) description of a negative relationship between Emotional Stability and Work- ing Excessively. Although not included in the model, a positive correlation was also found with the Extraversion personality variable $(r=.145, p=.01)$. Andreassen, Hetland and Pallesen (2010) found a positive relationship between addiction and the personality factors Responsibility, Extraversion and Openness to experience, and a negative relationship with Neuroticism and Kindness.

The second objective is verified partially because the best predictive model for the need to work includes two variables that act inversely: Emotional Stability and Self-esteem. The personality variable "Emotional Stability" was also included in this model as a negative predictor, in accordance with that found in other studies in which a negative relationship has been established between Emotional Stability and Excessive Work (Del Líbano, 2011). In the same way, Self-esteem has been included in this model as a negative predictor, in agreement with the results of other authors (Burke, 1999; Chamberlin \& Zhang, 2009; Wojdylo et al., 2013). 
Table 6. Summary of the predictive models for the criterion variables.

\begin{tabular}{lcccc}
\hline Predictor variables & \multicolumn{2}{c}{$\begin{array}{c}\text { Factor 1 } \\
\text { WCS-FW }\end{array}$} & \multicolumn{2}{c}{$\begin{array}{c}\text { Factor } 2 \\
\text { WCS-NW }\end{array}$} \\
\hline & $\begin{array}{c}\Delta \mathrm{R}^{2} \\
\text { Corrected }\end{array}$ & $\beta$ & $\begin{array}{c}\Delta \mathrm{R}^{2} \\
\text { Corrected }\end{array}$ & $\beta$ \\
\hline Op.ES Emotional stability & .156 & -.187 & .024 & -.173 \\
Perfectionism & .037 & .270 & - & -- \\
Self-Esteem & .051 & -.265 & .121 & -.271 \\
\hline Total explained variance $(\%)$ & 24.40 & -- & 14,00 & -- \\
\hline
\end{tabular}

All the data are significant at $p<.01$ (bilateral).

Some of the variables were excluded from the models. Impulsivity was not included although it had been identified as an important predisposing factor in other types of addictions (Cao et al., 2007; Choi, Kim et al., 2014; Choi, Park et al., 2014; Ding et al., 2014; Lee et al., 2012; Metcalf and Pammer, 2014; Nuyens et al., 2016), and was positively associated with the desire for alcohol and caffeine (Stamates \&

\section{References}

Andreassen, C.S., Hetland, J., \& Pallesen, S. (2010). The relationship between 'workaholism', basic needs satisfaction at work and personality. European Journal of Personality, 24, 3-17. Doi: 10.1002/per.737

Andreassen, C.S., Ursin, H., \& Eriksen, H. R (2007). The relationship between strong motivation to work, "workaholism", and health. Psychology and Health, 22, 615-629. Doi: 10.1080/14768320600941814

Baessler, J., \& Schwarcer, R. (1996). Evaluación de la autoeficacia: Adaptación española de la escala de Autoeficacia General [Evaluation of efficacy: Spanish adaptation of the General Self-Efficacy Scale]. Ansiedady Estrés, 2, 1-8.

Belloch, A., Cabedo, E., Morillo, C., Lucero, M., \& Carrió, C. (2003). Diseño de un instrumento para evaluar las creencias disfuncionales del trastorno obsesivo-compulsivo: resultados preliminares del Inventario de Creencias Obsesivas (ICO). International Journal of Clinical and Health Psychology, 3.135-150.

Burke, R. J. (1999). Workaholism in organizations: measurement validation and replication. International Journal of Stress Management, 6, 45-55. Doi: https://doi.org/10.1023/A:1021910303807

Burke, R. J. (2000a). Workaholism and divorce. Psychological Reports, 86, 219220. Doi: $10.2466 /$ pr0.2000.86.1.219

Burke, R. J. (2000b). Workaholism in organisations: The role of personal beliefs and fears. Anxiety, Stress and Coping, 13, 53-64. Doi: $10.1080 / 10615800008248333$

Burke, R. J., Matthiesen, S.B., \& Pallesen, S. (2006). Personality correlates of workaholism. Personality and Individual differences, 40, 1223-1233. Doi: 10.1016/j.paid.2005.10.017

Cao, F. L., Su, L. Y., Liu, T. Q., \& Gao, X. P. (2007). The relationship between impulsivity and Internet addiction in a sample of Chinese adolescents. European Psychiatry, 22, 466-471.Doi: http://dx.doi.org/10.1016/j.eurpsy.2007.05.004.

Chamberlin, C.M., \&Zhang, N. (2009). Workaholism, health and self acceptance. Journal of Counseling and Development, 87, 159-169.Doi: 10.1002/j.1556-6678.2009.tb00563.x

Chico, E., Tous, J. M., Lorenzo-Seva, U., \& Vigil-Colet, A. (2003). Spanish adaptation of Dickman's impulsivity inventory: its relationship to Eysenck's personality questionnaire. Personality and Individual Differences, 35 , 1883-1892. Doi: https://doi.org/10.1016/S0191-8869(03)00037-0

Choi, J. S., Park, S. M., Lee, J., Hwang, J. Y., Jung, H. Y., Choi, S. W., \& Lee, J. Y. (2013). Resting-state beta and gamma activity in Internet addiction. International Journal of Psychophysiology, 89, 328-333.Doi: http://dx.doi.org/10.1016/j.ijpsycho.2013.06.007.
Lau-Barraco, 2017). And the variable Self-efficacy was not included in the predictive model either, contrary to the indications of Salanova, Grau, Llorens and Schaufeli (2001) who claim that self-efficacy generates well-being and that the relationship between Work, Self-efficacy and Work Addiction is positive. In addition, other authors have suggested that high levels of Self-efficacy may be related to high levels of work addiction $(\mathrm{Ng}$, Sorensen \& Feldman, 2007).

The present research contributes to the knowledge of Work craving in several aspects that include Impulsivity, Personality (Extraversion, Emotional stability, Conscientiousness, Agreeableness, Openness to experience), Perfectionism, Self-esteem and Self-efficacy. The results have important practical implications with regard to the addiction to work that should be considered for the appropriate strategic management of human resources within organizations. The most notable among these are the need to promote the enhancement of self-esteem and emotional stability.

Choi, S. W., Kim, H. S., Kim, G. Y., Jeon, Y., Park, S. M., Lee, J. Y., ... Kim, D. J. (2014). Similarities and differences among Internet gaming disorder, gambling disorder and alcohol use disorder: A focus on impulsivity and compulsivity. Journal of Behavioral Addictions, 3, 246-253. Doi: http://dx.doi.org/10.1556/jba.3.2014.4.6.

Davison, G.C., \& Neale, J.M. (1990). Abnormal psychology (5th ed.). New York, NY: Wiley and Sons.

Del Libano, M. (2011). A journey into the heart of workaholism: Empirical findings from several multi-sample studies. Tesis doctoral no publicada, UJI. Castellón, España.

Dell'Oso, B., Altamura, A.C., Allen, A., Marazziti, D., \& Hollander, E. (2006). Epidemiologic and clinical updates on impulse control disorders: A critical review. European Archives of Psychiatry and Clinical Neurosience, 256, 464-475. Doi: https://doi.org/10.1007/s00406-006-0668-0

Dickman, S. J. (1990). Functional and dysfunctional impulsivity: personality and cognitive correlates. Journal of personality and social psychology, 58, 95.

Ding, W. N., Sun, J. H., Sun, Y. W., Chen, X., Zhou, Y., Zhuang, Z. G., .. Du, Y. S. (2014). Trait impulsivity and impaired prefrontal impulse inhibition function in adolescents with Internet gaming addiction revealed by a Go/No-Go fMRI study. Behavioral and Brain Functions, 10, 20. Doi: http://dx.doi.org/10.1186/1744-9081-10-20.

Griffiths, M. D., Demetrovics, Z., \& Atroszko, P. A. (2018). Ten myths about work addiction. Journal of behavioral addictions, 7, 845-857.

Hameed, F., Amjad, S., \& Hameed, A. (2013). The relationship between Workaholism and Personality. Middle-East Journal of Scientific Research, 17, 898-907.

Hernández, R., Fernández, C., \& Baptista, P. (2000). Metodología de la investigación [Research metodology]. México: McGraw-Hill.

Hill, R. W., Huelsmann, T. J., Furr, R. M., Kibler, J., Vicente, B. B., \& Kennedy, C. (2004). A new measure of perfectionism: The Perfectionism Inventory. Journal of Personality Assessment, 82, 80-91. Doi: 10.1207/s15327752jpa8201_13

Kerlinger, F.N. (2001). Investigación del comportamiento: Métodos de investigación en ciencias sociales. México: McGraw-Hill.

Lee, H. W., Choi, J. S., Shin, Y. C., Lee, J. Y., Jung, H. Y., \& Kwon, J. S. (2012). Impulsivity in Internet addiction: A comparison with pathological gambling. Cyberpsychology, Behavior and Social Networking, 15, 373-377. Doi: http://dx.doi.org/10.1089/cyber.2012.0063.

Martín-Albo, J., Núñez, J. L., Navarro, J. G., \& Grijalvo, F. (2007). The Rosenberg Self-Esteem Scale: translation and validation in university students. The Spanish journal of psychology, 10, 458-467. 
Mazzetti, G., Schaufeli, W. B., \& Guglielmi, D. (2014). Are Workaholics Born or Made? Relations of Workaholism with Person Characteristics and Overwork Climate. International Journal of Stress Management, 21, 227254. Doi: http://dx.doi.org/10.1037/a0035700

McDonald, R. P. (1999). Test theory: A unified treatment. Mahwah: Lawrence Erlbaum Associates, Inc.

McMillan, L. H. W., \& O’Driscoll, M. P. (2006). Exploring new frontiers to generate an integrated definition of workaholism. In R. J. Burke (Ed.), Research companion to working time and work addiction (pp. 89-107). Cheltenham, UK: Edward Elgar.

Metcalf, O., \& Pammer, K. (2014). Impulsivity and related neuropsychological features in regular and addictive first person shooter gaming. $C y$ berpsychology, Behavior and Social Networking, 17, 147-152. Doi: http://dx.doi.org/10.1089/cyber.2013.0024.

Mudrack, P.E. (2004). Job involvement, obsessive-compulsive personality traits, and workaholic behavioral tendencies. Journal of Organizational Change Management, 17, 490-508. Doi: 10.1108/09534810410554506.

Ng, T.W.H., Sorensen, K.L., \& Feldman, D.C. (2007). Dimensions, antecedents, and consequences of workaholism: A conceptual integration and extension. Journal of Organizational Behavior, 28, 111-136. Doi: $10.1002 /$ job.424

Nuyens, F., Deleuze, J., Maurage, P., Griffiths, M. D., Kuss, D. J., \& Billieux, J. (2016). Impulsivity in multiplayer online battle arena gamers: Preliminary results on experimental and self-report measures. Journal of Behavioral Addictions, 5, 351-356. Doi: http://dx.doi.org/10.1556/2006.5.2016.028

Oates, W.E. (1968). On being a 'workaholic' (a serious jest). Pastoral Psychology, 19, 16-20. Doi: https://doi.org/10.1007/BF01785472

Porter, G. (1996). Organizational impact of workaholism: Suggestions for researching the negative outcomes of excessive work. Journal of Occupational Health Psychology, 1, 70-84. Doi: http://dx.doi.org/10.1037/1076-8998.1.1.70

Robinson, B. E. (2007). Chained to the desk: A guidebook for workabolics, their partners and children and the clinicians who treat them. New York, NY: New York University Press.

Rosenberg, M. (1965). Society and adolescent self-image. Princeton, NJ: Princeton University.

Salanova, M., Grau, R., Llorens, S., \&Schaufeli, W.B. (2001). Exposición a las tecnologías de la información, burnout y engagement: El rol modulador de la autoeficacia [Exposure to information technologies, burnout and engagement: The moderator role of self-efficacy]. Revista de Psicología Social Aplicada, 11, 69-90.

Sanjuán, P., Pérez, A.M., \& Bermúdez, J. (2000). Escala de autoeficacia general: Datos psicométricos de la adaptación para población española [The general self-efficacy scale: psychometric data from the Spanish adaptation]. Psicothema, 12, 509-513.

Schaufeli, B. W., Shimazu, A., \& Taris, T. W. (2009). Being driven to work excessively hard. The evaluation of a two-factor measure of workahol- ism in the Netherlands and Japan. Cross-Cultural Research, 43, 320-348. Doi: $10.1177 / 1069397109337239$

Scott, K.S., Moore, K.S., \&Miceli, M.P. (1997). An exploration of the meaning and consequences of workaholism. Human Relations, 50, $287-$ 314. Doi: https://doi.org/10.1177/001872679705000304

Serrano-Fernández, M. J., Boada-Grau, J., Assens-Serra, J., Boada-Cuerva, M., \& Vigil-Colet, A. (n.d.). Spanish adaptation of the Work Craving Scale (WCS). Manuscript not published. Department of Psychology, University Rovira i Virgili, Tarragona, Spain.

Slade, P. D., \& Owens, R. G. (1998). A dual process model of perfectionism based on reinforcement theory. Behavior Modification, 22, 372-390. Doi: $10.1177 / 01454455980223010$

Stamates, A. L., \& Lau-Barraco, C. (2017). Environmental context effects on craving among consumers of caffeinated alcohol beverages: Associations with aspects of impulsivity. Experimental and Clinical Psychopharmacology, 25, 503-511.Doi: http://dx.doi.org/10.1037/pha0000160

Stoeber, J., \& Otto, K. (2006). Positive conceptions of perfectionism: Approaches, evidence, challenges. Personality and Social Psychology Review, 10, 295-319. Doi: 10.1207/s15327957pspr1004_2

Terry-Short, L., Owens, R. D., Slade, P. D., \& Dewey, M. (1995). Positive and negative perfectionism. Personality and Individual Differences, 18, 663 668. Doi: 10.1016/0191-8869(94)00192-U

Van Wijhe, C., Peeters, M. C. W., \& Schaufeli, W. B. (2014). Enough is enough! Cognitive antecedents of workaholism and its aftermath. $\mathrm{Hu}$ man Resource Management, 53, 157-177. Doi: 10.1002/hrm.21573

Vigil-Colet, A, Morales-Vives, F., Camps, E., Tous, J., \& Lorenzo-Seva, U. (2013). Development and validation of the Overall Personality Assessment Scale (OPERAS). Psicothema, 25, 100-106.

Wojdylo, K. (2007). Koncepcja osobowościowych wyznaczników pracoholizmu. [A conception of personal determinants of workaholism]. Studia Psychologiczne, 45, 53-67.

Wojdylo, K. (2010a). Funkcjonowanie pracoholików w sytuacji zadaniowej [Functioning of workaholics in the task situation]. Pryeglad Psychologiczny, 53, 75-98.

Wojdylo, K. (2013). Work Craving - the theory of work addiction. Nauka 3, 87-97.

Wojdylo, K., Baumann, N., Buczny, J., Owens, G., \&Kuhl, J. (2013). Work craving: A conceptualization and measurement. Basic and Applied Social Psychology, 35, 547-568. https://doi.org/10.1080/01973533.2013.840631

Wojdylo, K., Baumann, N., \& Kuhl, J. (2017). The firepower of work craving: When self-control is burning under the rubble of selfregulation. PloS one, 12, e0169729. Doi: 10.1371/journal.pone.0169729

Wojdylo, K., Karlsson, W., \& Baumann, N. (2016). Do I feel ill because I crave for work or do I crave for work because I feel ill? A longitudinal analysis of work craving, self-regulation, and health. Journal of Behavioral Addictions, 5, 90-99. Doi: https://doi.org/10.1556/2006.5.2016.005 